\title{
Women in Urban Local Government in Bangladesh: A Study on Narayanganj City Corporation
}

\author{
Jannatul Ferdous ${ }^{1 *}$, Md. Nahidul Islam² \\ 1,2Department of Public Administration, Faculty of Social Science, Comilla University, \\ Cumilla-3506, Bangladesh.
}

Received: 2021-04-18; Accepted: 2021-10-18; Published: 2021-10-31

\begin{abstract}
Women's equal participation in politics is critical to women's advancement. This determination, however, is not to be made uniformly across the globe. Yet, in contemporary periods, it has witnessed a significant shift in women's political participation globally. The purpose of this paper is to gain a better understanding of women's overall participation, their socioeconomic status, and their valuable role in urban policy formulation and implementation in Bangladesh. In this analysis, primary and secondary data are integrated. Primary sources are referenced to substantiate theories and arguments asserted in the secondary literature, which are based on the case study of Narayanganj City Corporation. It is completed with the assistance of theories and contentions gleaned from secondary sources. Additionally, this study concludes with an examination of Bangladeshi women's position in the decision-making process. Another pressing need is to broaden the participation of women in political culture at the grassroots level. In urban areas, the City Corporation must interact with various government, autonomous, and semi-autonomous bodies. The situation of female ward councillors has deteriorated to the point where there is some ambiguity. Women's involvement in politics has been limited by a decline in financial capital and family support. Women can appeal to low-level politics thanks to a patriarchal viewpoint. In Bangladesh, women continue to struggle for equal rights and face political challenges. Societal norms enforce gender stereotypes. Religious restrictions are the most severe concern among Bangladesh's status issues, which have a complicated structure. Women are not politically socialized enough to participate in the political life of their country. The City Corporation's institutional rules and responsibilities are of little concern to women, and the existing regulations are insufficient. Therefore, the paper can reveal the actual scenario of women's representation and obstacles in the urban level of Bangladesh.
\end{abstract}

Keywords: City corporation; Politics; Urban Local Government; Women

How to Cite: Ferdous, J., \& Islam, M. N. (2021). Women in Urban Local Government in Bangladesh: A Study on Narayanganj City Corporation. Journal of Contemporary Governance and Public Policy, 2(2), 92-105. https://doi.org/10.46507/jcgpp.v2i2.36.

Permalink/DOI: https://doi.org/10.46507/jcgpp.v2i2.36 


\section{Introduction}

As a frequently used catchphrase, empowerment takes on a variety of forms. It is a social fact that enables individuals or groups to be more capable or empowered to manage their daily lives more effectively. Legal empowerment studies are frequently concerned with increasing disadvantaged individuals' or groups' access to justice (Khair, 2008). In general, empowerment refers to the assertion and attainment of some form of authority or agency that enables individuals to perform specific tasks and achieve specific goals (Kabeer, 1999). In both senses, empowerment is frequently defined in terms of individualism but has broader social and political implications. South Africa's struggle for democracy overshadowed gender dynamics in the 1980s (Hassim, 2002). The emergence of a new democracy and women's autonomy to participate in politics resulted in the emergence of contemporary gender discourses. In the 1990s, the mantra was 'gender democratization' to eradicate gender discrimination and inequity (Silova \& Magno, 2004). The transformation of patriarchal state structures saw a shift in emphasis away from racial injustice and gendered democracy, with women represented at all government levels. Women's oppression and subjugation throughout history raise the issue of women's rights in our new era. Gender equity advocates emphasize that women's rights are human rights.

In recent years, the world has seen a significant shift in women's political participation because women have distinct values, perspectives, and capacities from men and act accordingly. As a result, their involvement in decision-making will shed new light on how they will exercise power. The extent to which women are represented and involved in the local government reflects a country's development level (Jayal, 2005). The role of women in leadership positions has been a point of contention for the last two decades. At the global level, United Nations women's conferences have emphasized the critical need to increase women's decision-making positions. In Asia and the Pacific, efforts to increase female political participation have focused primarily on female leadership at the central government level.

Nonetheless, women have always been an integral part of their society, playing an active role in community life, public organizations, and cities and municipalities. Local government is significantly closer to this level of involvement and frequently serves as an entry point into a party-political decision-making arena (Siddika \& Rahman, 2010). The purpose of this paper is to gain a better understanding of women's overall participation, their socioeconomic status, and their valuable role in urban policy formulation and implementation in Bangladesh. The study allows the integration of secondary and primary data. Primary sources are cited in support of theories and arguments advanced in the secondary literature, based on Narayanganj City Corporation's case study. To find out the scenario of women representatives in urban local government in Bangladesh is the general objective of the study.

\section{Research Methods}

The research was conducted using a mixed-method approach. The investigators gather and analyze data, combine the findings, and demand inferences using qualitative and quantitative methods (Tashakkori \& Creswell, 2007). Maintain the 
presence of the study, and the current research includes both qualitative and quantitative evidence.

\section{Profile of the Research Area}

We carried out this research in Bangladesh's Narayanganj City Corporation. Narayanganj is a city in Bangladesh's central region. It is located in the Narayanganj District, close to Dhaka, and has approximately 2.2 million people. It is Bangladesh's third-largest district. The Shitalakshya River runs through the community.

\section{Study Population \& Sampling}

The total sample size of this study was 100 (hundred) from the study area Narayanganj City Corporation. Purposive sampling system used for the selection of the respondent. The researchers were partially involved in data collection. However, more than one city corporation may serve the study purpose well. This is the fundamental limitation of the study.

Table 1 Research Area and Number of Respondents

\begin{tabular}{lc}
\multicolumn{1}{c}{$\begin{array}{c}\text { Type of } \\
\text { respondents }\end{array}$} & $\begin{array}{c}\text { Number of } \\
\text { respondents } \\
\text { Narayanganj City } \\
\text { Corporation) }\end{array}$ \\
\hline Male Representatives & 5 \\
\hline $\begin{array}{l}\text { Female } \\
\text { Representatives }\end{array}$ & 5 \\
\hline Officials & 5 \\
\hline Civil Society & 5 \\
\hline General Citizens & 80 \\
\hline Total & $\mathbf{1 0 0}$ \\
\hline
\end{tabular}

Source: Processed by the Authors (2020)

\section{Data Collection Methods}

To achieve the research aims, a variety of data collection procedures were utilised in this study. The questionnaire survey and the key informant interview were the two most important data collection strategies used in the study. The data collection approach used was mostly a questionnaire survey method of gathering information. There was also a question that was asked, which allowed for greater flexibility in how the respondents expressed their ideas, which contributed to the achievement of the study's aims. In addition to a questionnaire survey, the study relied on in-person interviews to gather primary information. To conduct this study, interviews were also conducted with a variety of people who were participating in face-to-face discussions. Twenty interviews were conducted to gain a better understanding of the situation of women representatives in urban local government in Bangladesh, using the interview guide and the discussion of the results of the questionnaire. Furthermore, content analysis entails gathering information from all relevant books, papers, journals, articles, disseminated and uncirculated research efforts, and articles, among other sources.

\section{Data Analysis and Presentation}

The diversified answer groups would utilize numerous issues to measure a complex variable, and identical items were recognized in an appropriate method with five answer clusters, score 1 to 5 . In the scale structure, response arranges through numerous substances were being counted. The evidence was studied, implied, tabulated, and well-ordered to accept the data scrutiny appreciative of the research's determination (Kumar, 2011). An outcome is available through graphs, tables, narrative writing, simple designs, and balanced consideration. They have sustained the analysis concerning the research questions and objective. 
Results and Discussion

\section{The Present Status of Women in Bangladesh's Urban Local Government}

Gender equality and local government are closely connected. They are essential for democratization and socioeconomic change. Women are the majority of the population. In comparison to men, who are adult males, and girls, who are female children, a woman is a mature female human being. The word woman (plural: women) may refer to biological sex differences, cultural gender roles, or a combination of the two (Khan \& Ara, 2006). Participation means collective and continuous efforts by the people themselves in setting targets, pooling resources together, and taking steps aimed at improving their living conditions. The term "participation" has both a narrow and broad meaning. In a strict sense, involvement refers to a specific activity in which a person takes part in a particular purpose. In a broader context, involvement refers to ordinary citizens' role and appointed officials, such as civil servants, in controlling government activities or providing guidance for community needs (Rahman, 1991). Empowerment refers to the reversal of male dominance systems by structural changes in the law, property rights, control over women's labour and bodies, and the institutions that support and perpetuate male dominance (Batliwala, 1994). Local government is concerned with the governance of a particular local area that is a political subdivision of a country, state, or another central political unit in political terms. It serves as the state's representative in the execution of its duties. In other words, the local government is an essential component of a country's democratic governance system. Then, as a legal term, it represents a corporate entity with a juristic citizen. Gender accessible local governance is a form of governance and a necessary aspect of good governance. Genderresponsive local government takes into account women's various needs, desires, importance, and concerns. It is required to state that the Bangladesh Constitution protects women's rights to a large extent. Bangladesh is also a signatory to key international agreements and mechanisms on gender equality (Hussain, 2018). The People's Republic of Bangladesh's constitution guarantees equal rights to all citizens. The constitution's Article 9 supports women's representation in the local government (Khan \& Ara, 2006).

Women are the majority of the population. The constitution of a democratic nation provides that the municipal government is legally recognized by Parliament or the introduction of relevant provisions (Panday \& Panday, 2008). Parliament passed numerous laws establishing City Corporations to represent small and medium-sized cities and metropolitan areas. Both the urban local government organizations' chartered roles are remarkably close, with 15 mandatory and 13 optional functions. However, it has been discovered that due to several factors such as a lack of funds, inadequate and erratic tax collection, the longterm existence of semi-autonomous and autonomous offices. And so on, both of these local metropolitan bodies are unable to carry out all of their prescribed functions (Siddique, 1994). It is important to note that city corporations do not function independently within the city limits in Bangladesh. These organizations must interact with various government, autonomous, and semi- 
autonomous bodies that operate in urban areas. The situation of women ward councillors has diluted till present there is different ambiguity. The study's consequential scenario has mainly been revealed in this study, which deliberates on tentative data arrangement, analysis of data from numerous angles. Firstly, it initiates the allotment of the respondents, their demographic view. It attempts to analyze the tentative explanation of the variables in line with the analytical framework.

\section{Demographical Presentation of Respondents}

Table 2 shows the age of the respondents. In this regard, the multiple types of involvement information various ages' respondents are ensured in this research work. Those respondents' ages are categorized into three types: below 20, 21-30, and 51-80. Here, most of the respondents (37\%) are female participants and belong to 2130 . On the other hand, most of the respondents (33\%) are male and belong to21-30 ages.

Table 2 Age of the Respondents

\begin{tabular}{|c|c|c|c|c|c|c|}
\hline \multirow[t]{4}{*}{$\begin{array}{l}\text { Age of } \\
\text { respondents }\end{array}$} & $\begin{array}{l}\text { Narayanganj } \\
\text { City } \\
\text { Corporation }\end{array}$ & Gender & $\begin{array}{l}\text { (Bellow } \\
20)\end{array}$ & $(21-50)$ & $(51-80)$ & Total \\
\hline & & Male & $6(6 \%)$ & $33(33 \%)$ & $12(12 \%)$ & \\
\hline & & Female & $7(7 \%)$ & $37(37 \%)$ & $5(5 \%)$ & \\
\hline & & Total & $13(13 \%)$ & $70(70 \%)$ & $17(17 \%)$ & $100(100 \%)$ \\
\hline
\end{tabular}

Source: Field Survey (2020)

Table 2 shows the age of the respondents. In this regard, the multiple types of involvement information various ages' respondents are ensured in this research work. Those respondents' ages are categorized into three types: below 20, 21-30, and 51-80. Here, most of the respondents (37\%) are female participants and belong to 2130 . On the other hand, most of the respondents (33\%) are male and belong to21-30 ages.

Table 3 Gender of the Respondents

\begin{tabular}{l|l|l|l}
\hline \multicolumn{4}{c}{ Narayanganj City Corporation } \\
\hline Types of respondents & Male & Female & Total \\
\hline Councilors & $12(12 \%)$ & $10(10 \%)$ & $22(22 \%)$ \\
\hline Officials & $6(6 \%)$ & $4(4 \%)$ & $10(10 \%)$ \\
\hline Civil society & $4(4 \%)$ & $6(6 \%)$ & $10(10 \%)$ \\
\hline General people & $28(28 \%)$ & $32(32 \%)$ & $60(60 \%)$ \\
\hline Total & $48(48 \%)$ & $52(52 \%)$ & $100(100 \%)$ \\
\hline & Source: Field Survey $(2020)$ & \\
\hline
\end{tabular}

Table 3 shows the gender of the respondents. Both males and females are joining in this study; basically, women participants got a priority. The male respondents of the Narayanganj City Corporation are $48 \%$, wherever female respondents are $52 \%$. 
Table 4 Educational Qualifications of the Respondents

\begin{tabular}{l|l|l|l}
\hline \multicolumn{4}{c}{ Narayanganj City Corporation } \\
\hline Category & Male & Female & Total \\
\hline Below SSC & $10(10 \%)$ & $20(20 \%)$ & $30(30 \%)$ \\
\hline SSC & $10(10 \%)$ & $12(12 \%)$ & $22(22 \%)$ \\
\hline HSC & $14(14 \%)$ & $10(10 \%)$ & $24(24 \%)$ \\
\hline Honors' & $8(8 \%)$ & $6(6 \%)$ & $14(14 \%)$ \\
\hline Master's & $6(6 \%)$ & $4(4 \%)$ & $10(10 \%)$ \\
\hline Total & $48(48 \%)$ & $52(52 \%)$ & $100(100 \%)$ \\
\hline
\end{tabular}

Source: Field Survey (2020)

Table 4 shows the educational qualifications of the respondents. Education qualification is illustrated into five stages like Bellow, S.S.C, H.S.C, Honors 'and Masters. Most male participants $(14 \%)$ belong to H.S.C education, and most of the female participants (20\%) belong to below S.S.C education. Female respondents are comparatively less educated than male respondents.

\section{Role of Women Members in Urban Government and their Effectiveness}

Figure 1 depicted the inspiration of participating local governments. Women's participation at the urban level is critical to ensuring development. Without their enthusiastic involvement in politics, the outcome will be impossible, as nearly half of the country's population is female. The preceding figure illustrates the source of inspiration for participating local governments. In this regard, $30 \%$ of respondents stated that female councillors entered the City Corporation election due to selfinspiration. Additionally, 30\% of respondents indicated that family members stimulated female councilors. Again, $30 \%$ of respondents stated that they were motivated by community members. Finally, 30\% of respondents said that local political parties encouraged female councilors.

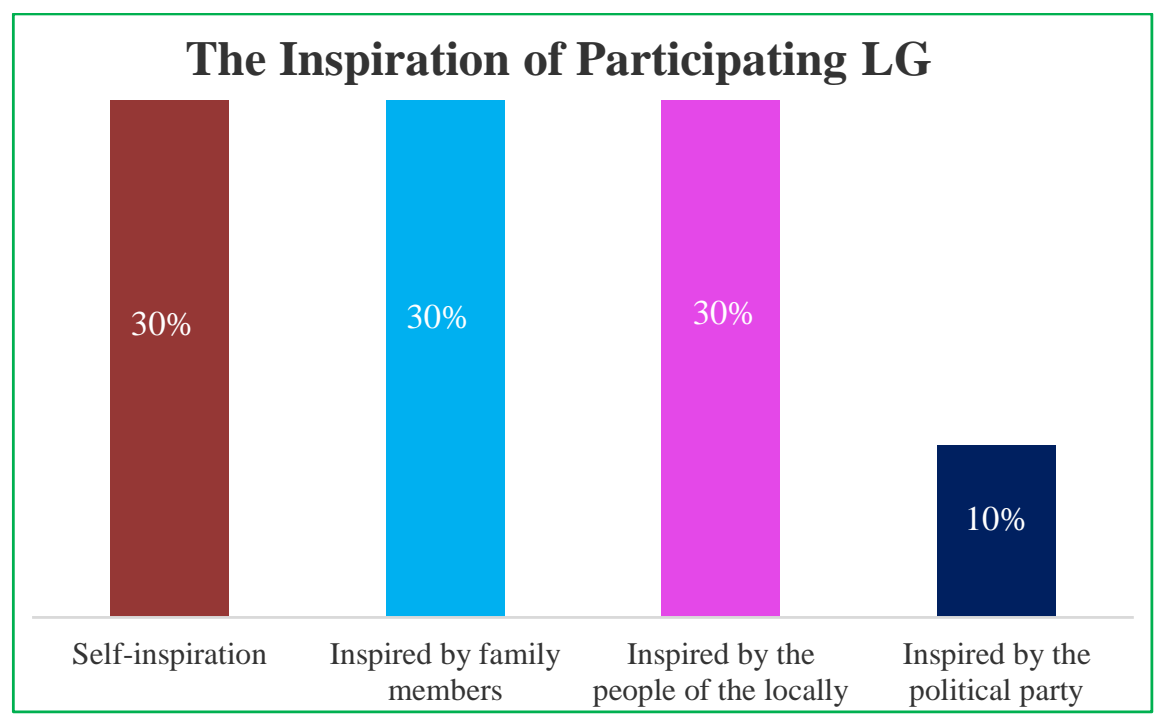

Figure 1 Inspiration of participating local government Source: Field Survey (2020) 
Table 5 Level of Participation in the Decision-Making Process Narayanganj City Corporation

\begin{tabular}{l|l}
\hline Criteria & Percentage \\
\hline Very high & $50 \%$ \\
\hline High & $10 \%$ \\
\hline Moderate & $20 \%$ \\
\hline Little & $15 \%$ \\
\hline Very little & $5 \%$ \\
\hline Total & $100 \%$ \\
\hline
\end{tabular}

Source: Field Survey (2020)

Table 5 shows the level of participation in the decision-making process. The City Corporation mayor has to make some policies along with the surviving policy. The majority of respondents (50 percent) indicated very high because female councillors of the Narayanganj City
Corporation are individually required to play a significant role in decision-making. However, they are alleged to be overlooked at times in providing their perspective. Additionally, the male councillor stated that female councillors are indifferent to various issues.

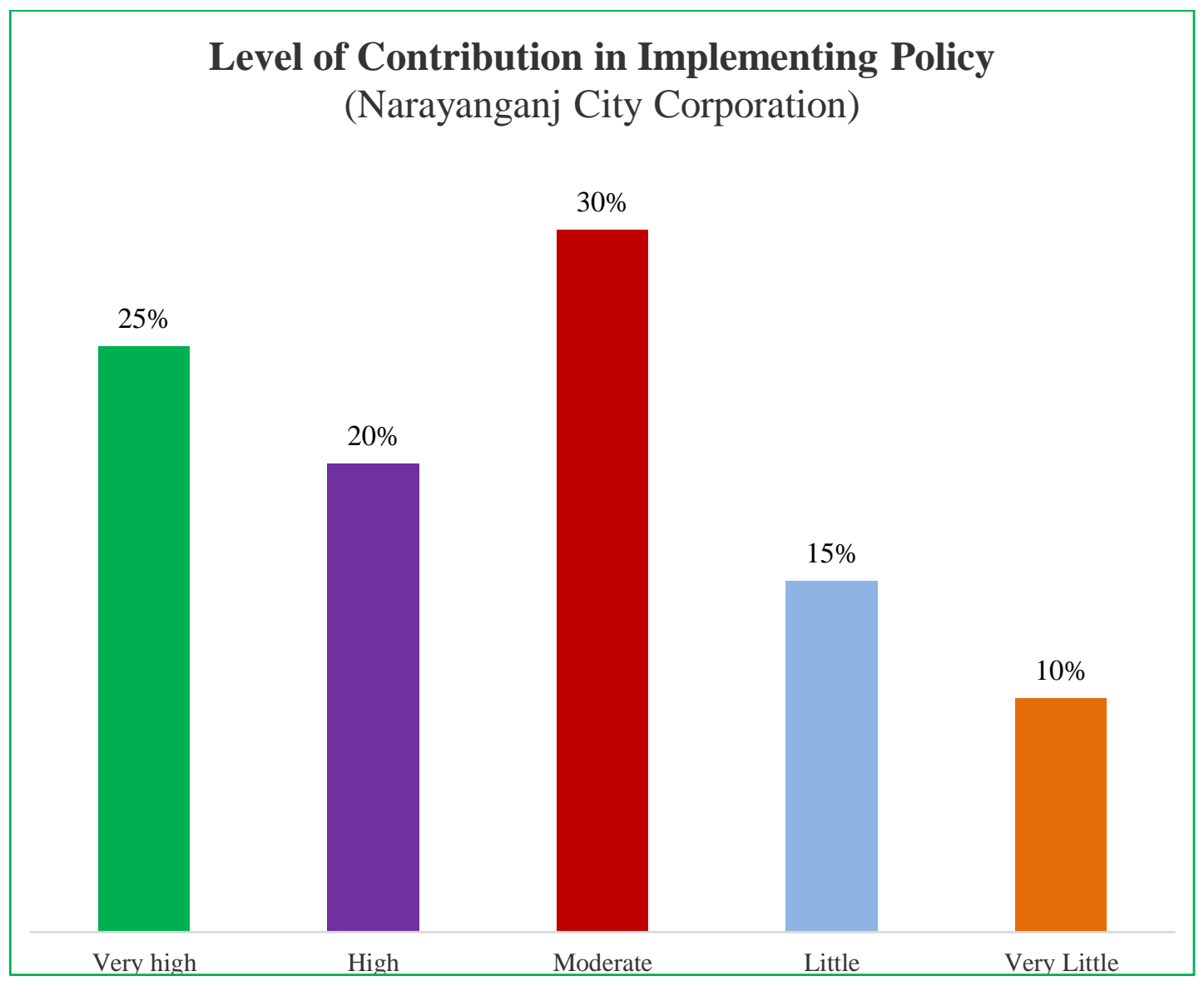

Figure 2 Level of contribution in implementing policy

Source: Field Survey (2020) 
Figure 2 shows the three wards. 25\% of respondents said participation in policy women councillors are required implementation. Representatives because they highly contribute to implement national guidelines. Male policy implementation. However, the councillors cannot alleviate women- male councillors supposed that they related problems, so the government are only a participant portion. has been created women councillor Therefore, they do not find sufficient post. Each ward councillor stands for opportunities to do for people.

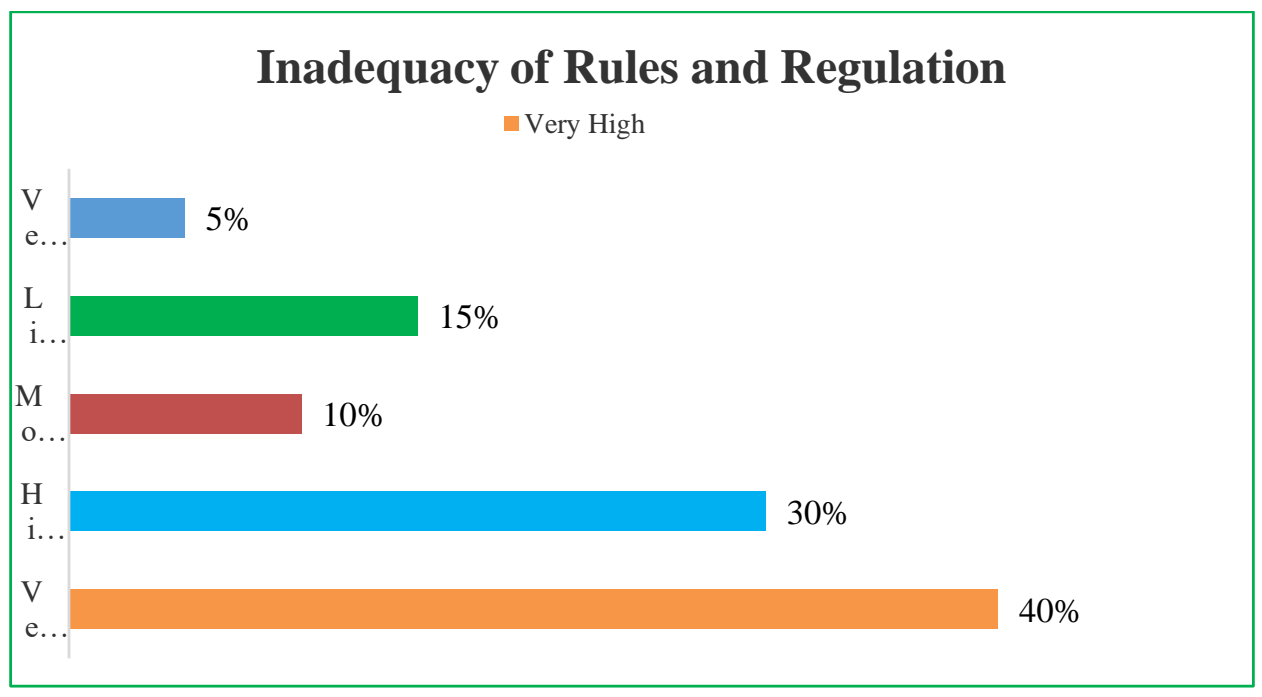

Figure 3 Inadequacy of existing rules and regulation Source: Field Survey (2020)

Figure 3 shows the inadequacy of existing rules and regulations. In this regard, $40 \%$ of the respondents (women councillors) said very high because current rules and regulation are not adequate. $30 \%$ of the respondents said high because mostly male councillor despoiled and they have ignored also.

\section{Political Problem to Participate in Election}

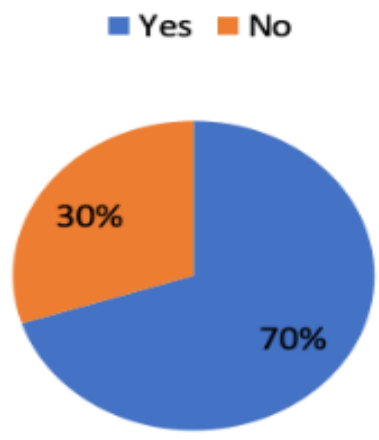

Figure 4 Political problem to participate in the election of Narayanganj City Corporation

Source: Field Survey (2020) 
Figure 4 shows the political problem situation in the manner of participating women in elections. Most of the respondents (70\%) said that there has a political problem with the election. Another 30\% of respondents said 'No' because there has no concerning level of the political crisis presented.

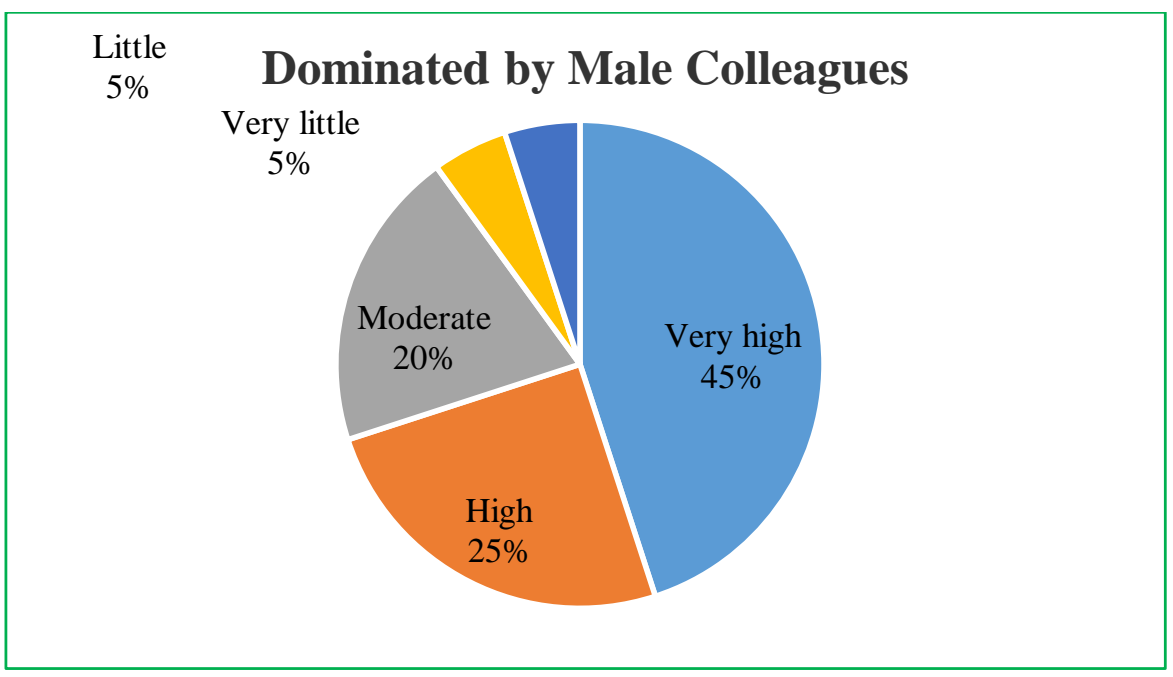

Figure 5 Dominated by male colleagues

Source: Field Survey (2020)

Figure 5 shows the dominated by male colleagues. Domination is a general tendency of people. Male and female councillors are functioning mutually for the development of people in the City Corporation. Most of the time, women councillors are suffering in the working sector by their opposite number. Forty-five percent of respondents said male colleagues very highly dominated them in this regard. And 20 percent of respondents said they dominated any case. But it may be smaller than before. $25 \%$ of respondents said that nobody is entirely free for this.

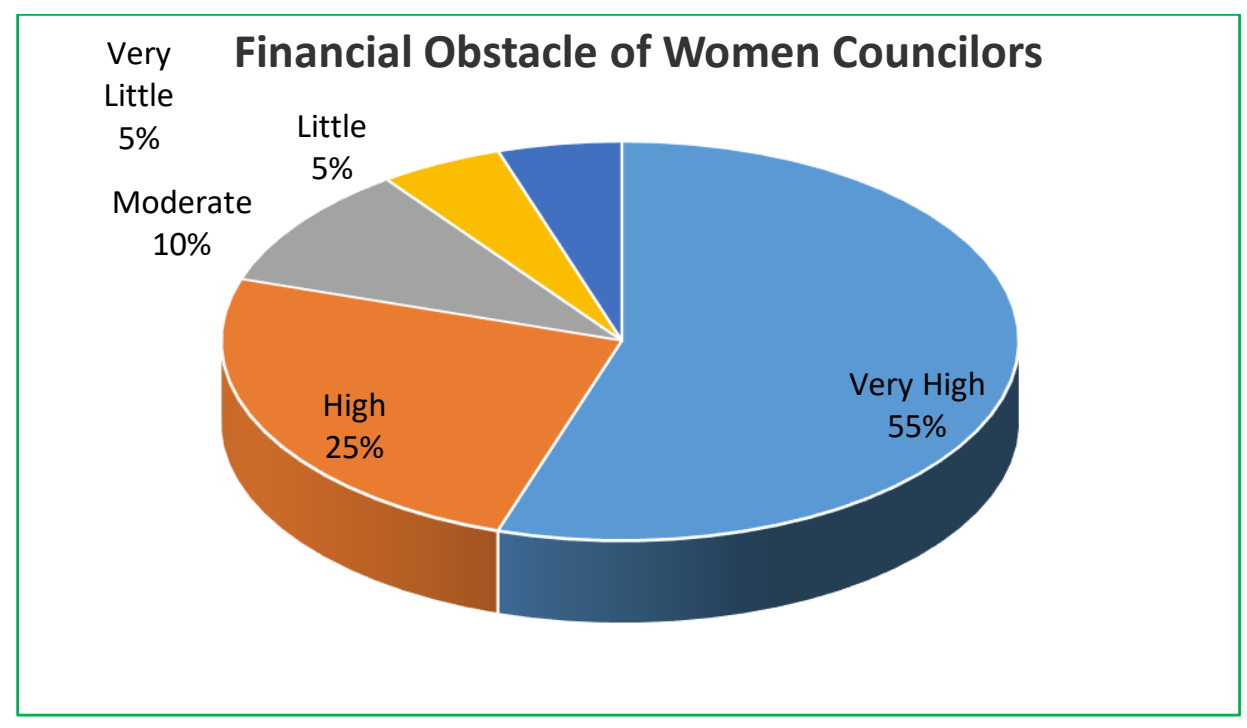

Figure 6 Financial obstacle of women councillors in Narayanganj Source: Field Survey (2020) 
Figure 6 shows the financial obstacle of women councillors. They argued that financial capability is a very needed thing for development. The city corporation provides a certain amount of funds for the development activities of the government. $55 \%$ of respondents said that the funds are allocated to the male councillors. So women councillors don't get any particular amount of development activities and depend on the mayor. Therefore, women councillors need more money than male councillors.

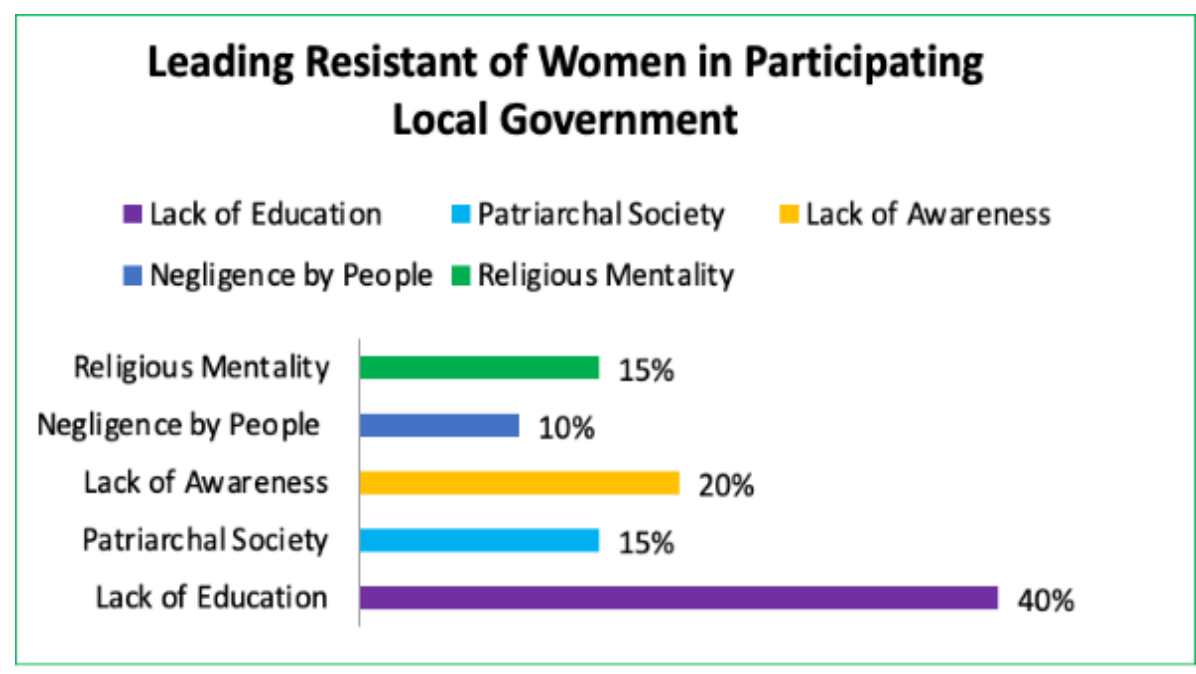

Figure 7 Leading resistance of women in participating local government Source: Field Survey (2020)

Figure 7 shows the maximum resistance of women in participating local government. Most of the respondents $(40 \%)$ said that the maximum resistance is lack of education. Another $15 \%$ of the respondents said that the difficulty is patriarchal culture. Again 20\% of the respondents spoke about a lack of awareness. Moreover, $10 \%$ of them said that people's negligence is a leading cause; the rest 15\% said lack of understanding is the primary resistance.

Table 6 Level of Promises Fulfilled by Women Councilor

Narayanganj City Corporation

\begin{tabular}{l|c}
\hline Criteria & Percentage \\
\hline Very high & $10 \%$ \\
\hline High & $15 \%$ \\
\hline Moderate & $60 \%$ \\
\hline Little & $10 \%$ \\
\hline Very little & $5 \%$ \\
\hline Total & $100 \%$ \\
\hline
\end{tabular}

Source: Field Survey (2020)

Table 6 shows the level of promises fulfilled by women councillors. Women reserve seats are only by name since they have chosen by voters. Most of the respondents $(60 \%)$ of the Narayanganj City
Corporation said they have moderately fulfilled their commitment. They want to get more opportunities to fulfil their promises completely. $10 \%$ of respondents said little because of various limitations. 


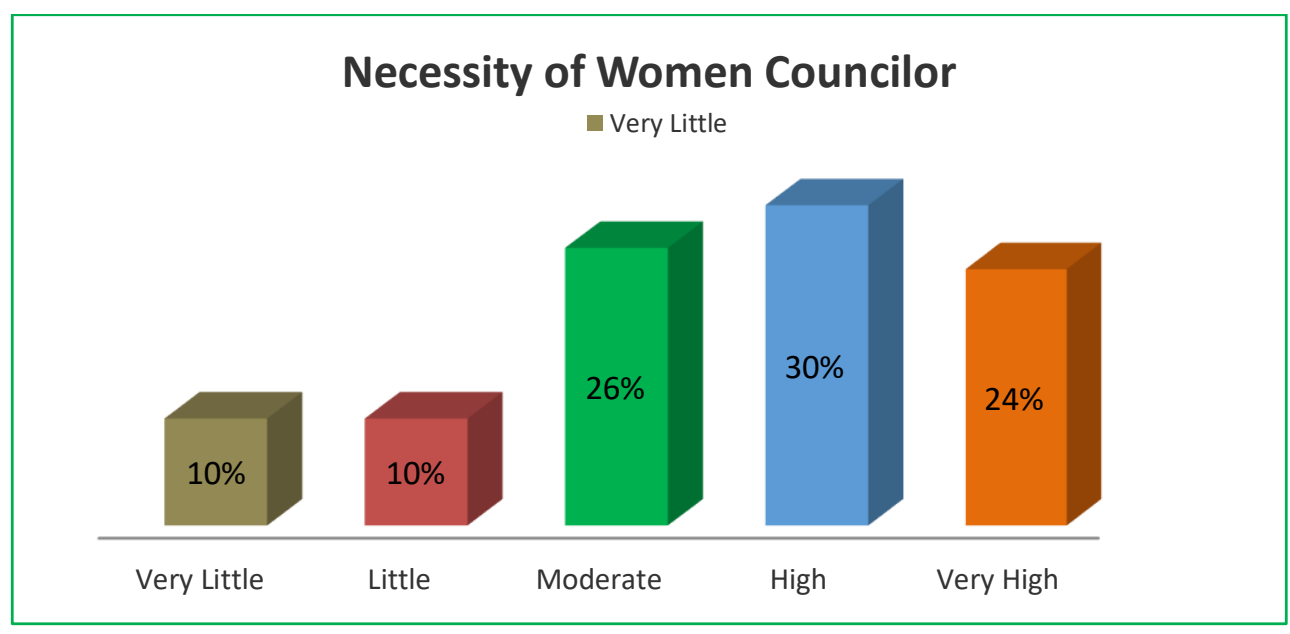

Figure 8 Necessity of woman councillor in City Corporation Source: Field Survey (2020)

Figure 8 shows the necessity of women councillor in the City Corporation. Women are complementary to men. Most of the respondents (30\%) percent said they are highly needed. As men's and women's troubles are not similar, the male councillor can't simply access the female that is very effortless for women. $26 \%$ of the respondent's idea woman councillor is moderately desirable. On the other hand, $10 \%$ of the City Corporation respondents said that women councillors' requirement is very slight because they don't have sufficient capacity. Occasionally it is exposed that they don't make out their responsibility.

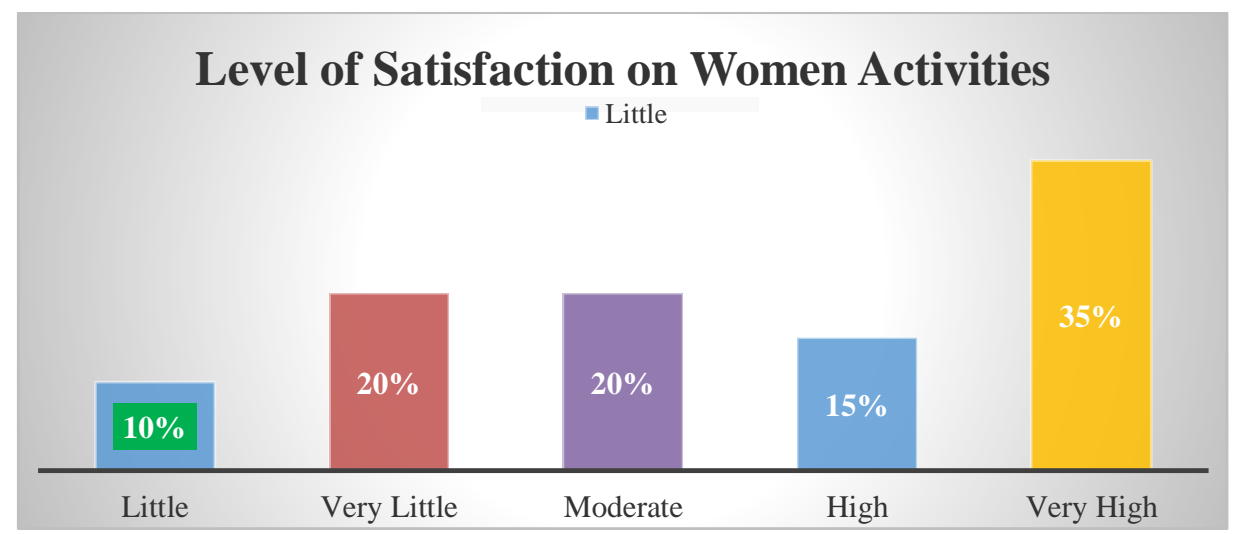

Figure 9 Level of satisfaction with women's activities Source: Field Survey (2020)

Figure 9 describes women's level of satisfaction with women's activities. The efforts of women leaders have made a difference in the degree of public happiness. Most of the respondents (35\%) said they are very highly satisfied since they get adequate support from the women representatives. $20 \%$ of respondents are moderately satisfied because they 
can meet female councillors and share any matter with female councillors than male councillors. $20 \%$ of the respondents said that they are somehow pleased. $10 \%$ of the respondents said there is no need as they don't perform anything they want.

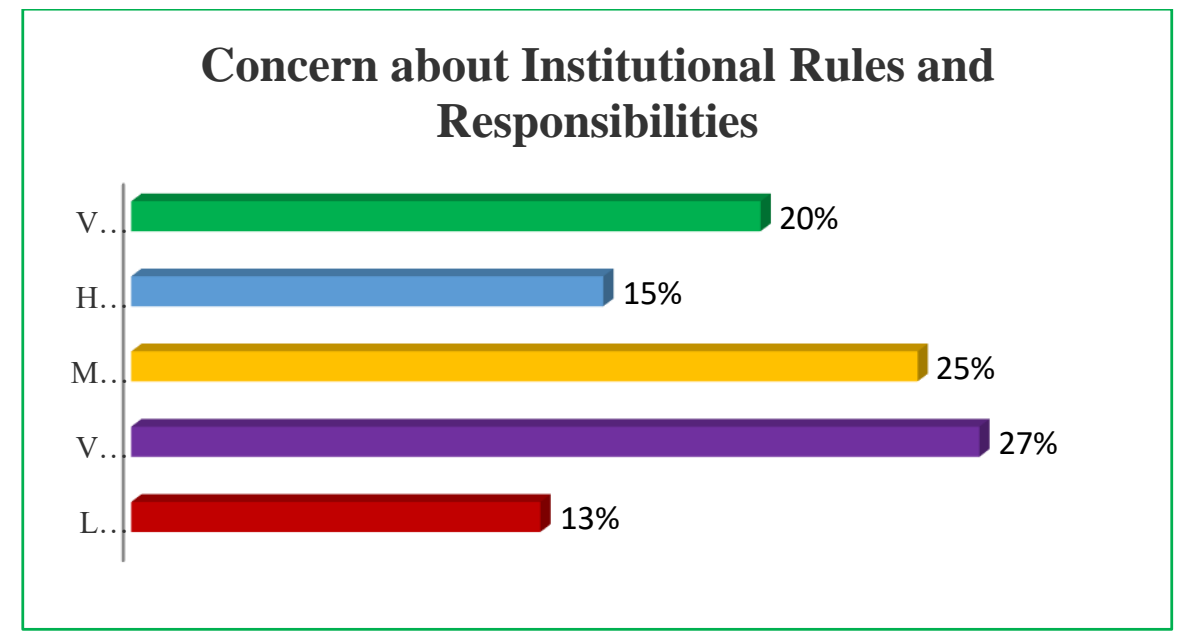

Figure 10 Concern about institutional rules and responsibilities Source: Field Survey (2020)

Figure 10 shows the concern about institutional rules and responsibilities. Women perform various works regarding the institutional regulations of the City Corporation. Most of the respondents $(27 \%)$ said they are very little concerned about institutional rules and responsibilities. $25 \%$ of respondents of the Narayanganj City Corporation are moderately worried about institutional regulations and obligations. Lastly, around 13\% of respondents frankly said little in response because they are not well worried by the City Corporation's existing rules and responsibilities.

\section{Main Findings of the Study}

Women empowerment is a holistic conception and multidimensional approach, including social, economic, and political characteristics. Women's involvement in politics was hampered by a shortage of financial resources and family support. A patriarchal viewpoint allows women to appeal to low-level politics. In Bangladesh, women are still fighting for equal rights and are still confronted with political issues (Nazneen, 2017). Societal norms enforce restrictive gender stereotypes. Religious restrictions are the most severe concern of status issues in Bangladesh, which follows a complex structure. Women are not sufficiently politically socialized to engage in the country's political life. Women are little concerned about the City Corporation's institutional rules, and responsibilities and existing rules and responsibilities are insufficient. They have not fulfilled their commitment. Lack of education is the maximum resistance of women in participating in local government. Women councillors don't get any specific amount of funds for performing development activities. Male colleagues heavily dominate female councillors. 


\section{Conclusion}

This paper demonstrated the study's demographic presentation by displaying age, gender, and educational attainment (Patterson, 2010). Then, decorated the role of the contribution and its effectiveness, women's decision making, and policy implementation impact was in the assessment

presentation (Aminuzzaman, 2017). Furthermore, conducted an assessment on the impediments to women's proper contribution, such as political issues, male colleagues' dominance, financial issues, and other difficulties. According to the respondents, leading the resistance, keeping promises, the required degree of women's involvement, and other topics in this paper determine women's current urban local government status (Huq, 2016) and that assessment scenario through various graphical presentations, tables, and other items and their investigative explanation. Finally, we can adequately comprehend the women's situation of Bangladesh in urban local government. However, it has been deliberate to show all the key outcomes, explanations, commendations, and assumptions through which the study has been established. Women should be more aware of their rights and the obligations of local government. The government should organize various training types on women's empowerment and politics to perform their duties effectively and develop capability. The current research used an empirical method to look into women members' situation in Bangladesh's urban local government. However, new research is needed to investigate from a sociological perspective. The study's results would be legalized if it was extended. This study focused on women socioeconomic status in urban local government, the position of women members in the metropolitan government, and their effectiveness in policymaking and policy implementation at the municipal level, but more research is needed. Further studies are desired for exploring women's weakness, which is frequently tricky through study. As Narayanganj is a new City Corporation, it will be helpful for the researcher to see the creation of such a new City corporation in the different research work.

\section{Acknowledgments}

The researchers did not receive any funding for this study. The researchers are extremely thankful to all respondents, data collectors, and note-takers.

\section{References}

Aminuzzaman, S. M. (2017). Study on Women Development and Empowerment: Policies and Issues. Retrieved from https://www.researchgate.net/p ublication/322655206_Study_on _Women_Development_and_Emp owerment_Policies_and_Issues

Batliwala, S. (1994). The Meaning of Women's Empowerment: New Concept from Action. Cambridge: Harvard University Press.

Hassim, S. (2002). A conspiracy of women: The women's movement in South Africa's transition to democracy. Social Research: An International Quarterly, 69(3), 693-732.

Huq, S. M. S. (2016). Women's participation in local Government: a tool for sustainable development of Bangladesh. European Journal of Business and Social Sciences, 4(11), 169-183.

Hussain, A. (2018). Mainstreaming Gender in Local Governance: Bangladesh Context. Retrieved 
23 March 2021, from The Daily Sun website: https://www.dailysun.com/post/294572/2018/03 /12/Mainstreaming-Gender-inLocal-Governance:-BangladeshContext

Jayal, G. N. (2005). From representation to participation: Women in local government. Journal of Administration and Diplomacy, 2(1), 72-79.

Kabeer, N. (1999). The conditions and consequences of choice: reflections on the measurement of women's empowerment. Geneva: UNRISD.

Khair, S. (2008). Legal Empowerment for the Poor and Disadvantaged: Strategies, Achievements and Challenges, Experiences from Bangladesh. Dhaka: Canadian International Development Agency.

Khan, M. R., \& Ara, F. (2006). Women, participation and empowerment in local government: Bangladesh union Parishad perspective. Asian Affairs, 29(1), 73-92.

Kumar, R. (2011). Research Methodology: a step-by-step guide for beginners. New Delhi: SAGE Publications India.

Nazneen, S. (2017). The Women's Movement in Bangladesh: A Short History and Current Debates. Dhaka: Friedrich- Ebert-Stiftung (FES).

Panday, P. K., \& Panday, P. K. (2008). The development of the urban government system in Bangladesh: does coordination exist? Local Government Studies, 34(5), 559-575.

Patterson, K. E. (2010). An analysis of demographic data and educational experiences that predict student success on the funeral service National Board Examination (Iowa State University, Digital Repository). Iowa State University, Digital Repository, Ames. https://doi.org/10.31274/etd180810-2867

Rahman, M. (1991). People's Participation at the Upazilla Level: Problems and Prospects. Bangladesh: Rajshahi University Press.

Siddika, A., \& Rahman, M. M. (2010). Women in local government. Retrieved 21 March 2021, from The Daily Star website: https://www.thedailystar.net/n ews-detail-167964

Siddique, K. (1994). Local Government in Bangladesh. Dhaka: University Press Limited.

Silova, I., \& Magno, C. (2004). Gender equity unmasked: democracy, gender, and education in Central/Southeastern Europe and the Former Soviet Union. Comparative Education Review, 48(4), 417-442.

Tashakkori, A., \& Creswell, J. W. (2007). The new era of mixed methods. Journal of Mixed Methods Research, Vol. 1, pp. 3-7. Sage Publications.

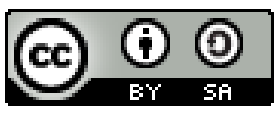

(C) 2021 by the Authors. Submitted for possible open access publication under the terms and conditions of the Creative Commons Attribution- ShareAlike (CC BY SA) license (https://creativecommons.org/licenses/by-sa/4.0/). 